\title{
CSF2RB wt Allele
}

National Cancer Institute

\section{Source}

National Cancer Institute. CSF2RB wt Allele. NCI Thesaurus. Code C51349.

Human CSF2RB wild-type allele is located in the vicinity of 22q13.1 and is approximately $17 \mathrm{~kb}$ in length. This allele, which encodes cytokine receptor common beta chain protein, is involved in signal transduction. Mutations in the gene that produce variant alleles are associated with the pathogenesis of that myeloproliferative disorder and protein alveolar proteinosis. 